\title{
A participatory action research on the care for water and life on Earth: a case study of interreligious and intercultural engagements in the time of the pandemic in Thailand Uma pesquisa de ação participativa sobre o cuidado com a água e a vida na Terra: um estudo de caso de compromissos inter-religiosos e interculturais na pandemia na Tailândia
}

$\operatorname{Rey} \mathbf{T y}^{1}$

\begin{abstract}
Resumo
This article presented a report on an ongoing research project that integrates culture, religion and the environment. Dialectically, the Bible guides this study in the same way that this project responded to the water crisis and the environmental realities obtaining in the real world today. The paper problematizes the lack of direct citizen action on the burning issue of caring for water and life on Earth. Specifically, this article presented a case study in Thailand that deals with a community participatory action research that involves environmental advocacy in the classroom at the university level on the one hand and environmental care through a planting project with the local intercultural and interreligious community on the other hand. The pandemic determines the ebb and flow of the progress of the project, including its sustainability.
\end{abstract}

Palavras-chave

COVID-19 pandemic. Environmentalism. Participatory action research. Intercultural and interreligious engagement. Water crisis.

\begin{abstract}
Este artigo apresenta o relato de um projeto de pesquisa em andamento que integra cultura, religião e meio ambiente. Dialeticamente, a Bíblia informou este estudo da mesma forma que este projeto respondeu à crise da água e às realidades ambientais existentes no mundo real hoje. $\mathrm{O}$ artigo problematiza a falta de ação cidadã direta sobre a questão candente do cuidado com a água e a vida na Terra. Especificamente, este artigo apresenta um estudo de caso na Tailândia que lida com uma pesquisa de ação participativa da comunidade que envolve a defesa do meio ambiente em sala de aula em nível universitário, por um lado, e o cuidado ambiental por meio de um projeto de plantio com a comunidade local intercultural e inter-religiosa, por outro. A pandemia determina o fluxo e refluxo do andamento do projeto, incluindo sua sustentabilidade.
\end{abstract}

Keywords

Pandemia de COVID-19. Ambientalismo. Pesquisa de ação participativa. Engajamento intercultural e inter-religioso. Crise hídrica.

\footnotetext{
${ }^{1}$ Doutor em Direitos Humanos e Educação para a Construção da Paz pela Northern Illinois University. Mestre em Ciências Políticas pela Northern Illinois University e em Estudos Asiáticos pela University of California. Professor do Departamento de Estudos da Paz do Instituto de Religião, Cultura e Paz da Payap University. Contato: reyty1@gmail.com.
} 
A participatory action research on the care for water and life on Earth

\section{INTRODUCTION: STATEMENT OF THE PROBLEM ${ }^{2}$}

There are problems that impinge upon the well-being of nature and society all over the world. Globally, we are confronted with climate crisis. Regionally in mainland Southeast Asia, forest burning engulf the region during the burning season from about February to May every year. Nationally in Thailand, forest and marine ecosystems are threatened as a result of deforestation and overfishing. There is much to be desired as far as the air quality in major cities, such as Bangkok and Chiang Mai, are concerned. Locally in northern Thailand, the air is thick of pollutants which necessitates almost compulsory facial mask wearing about three months a year, especially for those with respiratory ailments.

There are problems related to religion on the ground. Globally, on the one hand, there are acts of discrimination, hatred, and violence that people of one faith commit against people of another faith. On the other, there are people of different faiths who intentionally engage in interreligious dialogue. Thailand in general is an open society that accepts diversity with limitations. In such a predominantly Theravada Buddhist country, everyone accepts Buddhism as a way of life, regardless of your personal religious affiliations. People of different faiths are disconnected and stay in their own little corners and margins of society.

There are problems related to ethnicity and culture. In general, people from the majority population in a given society assumes that their culture is the normal culture. They feel that they do not have the need to learn about the cultures of people of different backgrounds. In this way, the minority is therefore marginalized and made invisible. In Thailand, the dominant culture is the central Thai culture, which coexist with the Muslim Malay culture in the south, the peasant-based culture in the East, and the Lanna culture in the north. In addition, there are many people who are officially called as members of hilltribes: Akha, Hmong, Karen, Lawa, Lahu, Lisu, Mien/Yao, Palaung, and more. The project will try to include people of various cultural backgrounds in the nearby areas.

Research questions: what are the lessons we can learn from the Bible about caring for water and life on Earth? What are the contradictions between nature and society with which humans are wrestling today? What are specific courses of action to address the issue of water and life on Earth?

\section{PURPOSE OF THE STUDY}

Based on the forgoing research questions, the purpose of this project is to reflect upon the teachings in the Bible about caring for water and life on Earth, the current situation of the natural world in relation to human society, and the courses of action that the community participatory action research undertakes dialectically in response to the current situation of

\footnotetext{
${ }^{2}$ This research was made possible with a research grant from the United Board for Christian Higher Education in Asia (UB) through the Institute for Advanced Study in Asian Cultures and Theologies (IASACT) of the Chinese University of Hong Kong (CUHK).

Caminhos de Diálogo, Curitiba, ano 9, n. 15, p. 156-176, jul./dez. 2021 


\section{Revista Brasileira de Diálogo Ecumênico e Inter-religioso}

Nature as well as to the lessons learned from the biblical texts. Together, there is a dialectical unity of observing, thinking about, and acting in the world (FREIRE, 2007). See figure 1 below:

FIGURE 1 - THE PURPOSE OF THE RESEARCH

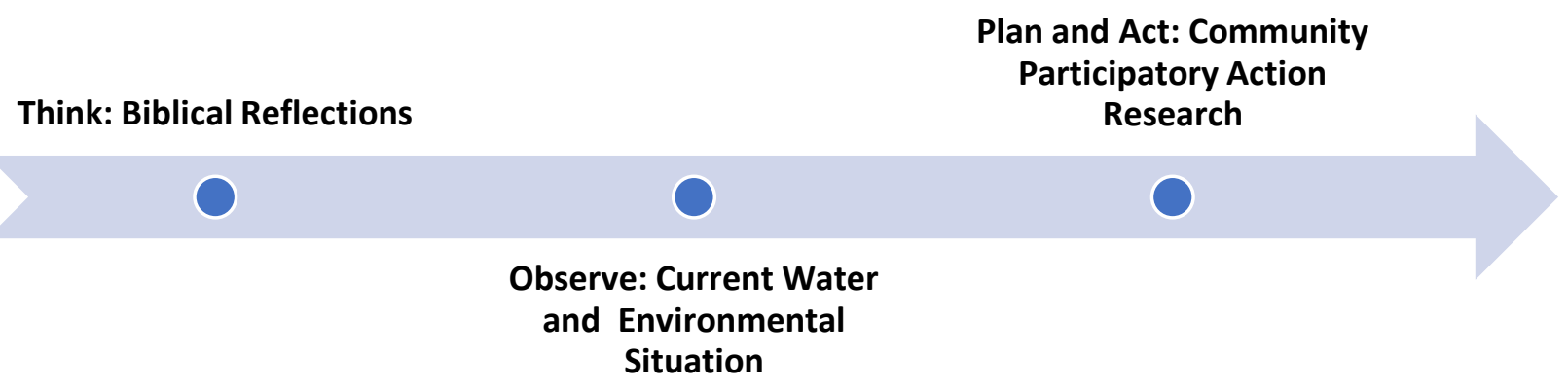

Source: The author.

\section{LITERATURE REVIEW}

This section discussed two major themes. The first theme explained the difference between (1) traditional research and (2) action research. The second theme discussed the different types of action research as well as situated this research in one of the variants of action research.

Marx aptly summed up the difference between traditional philosophy and research in his statement according to which all hitherto existing systems of knowledge merely described the world, the point is to change it. That is the essence of action research.

\subsection{Traditional research and action research}

This section discusses the general similarities and differences between traditional research and action research. Both traditional research (TR) and action research (AR) involve at least an investigator, a problem, and a gap to fill. But that is where the similarities end. Both TR and AR look at both theory and practice. However, TR emphasizes theory, with research questions relying on theories, while AR emphasizes practices, with research questions relying on social reality (WALSH; GRANT; COLEMAN, 2008). In TR, the investigator is a detached observer, while in AR, the investigator is an active participant (ZYCH; BERTA; GAGLIARDI, 2020). In TR, the research is based on the gap in the literature, whereas in AR, practical problem is encountered in real life, whether in the classroom setting in society at large (KRUMPERS; BRANDES; GEBHARDT; KUHNEMUND, 2021). The aim of TR is to fill a research gap through contribution of the study to advance new knowledge, while the aim of AR is to decide on ameliorate certain conditions in order to solve practical problems in real world situations. TR focuses on concepts, theories, empirical studies, data collection, data analysis, and publication while AR focuses on responses to social needs, action learning, practical work, a given local setting, and social change (BILORUSKY, 2021). TR gives attention to the 
A participatory action research on the care for water and life on Earth development of a theory and the implications of the research, while AR pays homage to the experiences and accounts of people involved in actions for the improvement of certain situations and for social change (GULLION; TILTON, 2020).

Some researchers are not satisfied with traditional pure research or applied research. They want to bring about social transformation in real-life issues as well as ameliorate the general, environmental, economic, social cultural, political, and human conditions under which communities and societies exist. Hence, they engage in action research. As such, they are not merely observers but are participants actively engaged in direct transformative action. People engaged in action research are therefore scholar-activists (ACTION RESEARCH CENTER, 2021). See figure 2 below:

FIGURE 2 - DIFFERENCE BETWEEN TRADITIONAL RESEARCH AND ACTION RESEARCH

\section{Differences}

\section{Traditional Research}

Researcher is detached

\section{Action Research}

Research is involved in change

Source: The author.

\section{DIFFERENT TYPES OF ACTION RESEARCH}

There are diverse variants of action research, among which include the following: (1) action research as such (STRINGER; ARAGON, 2020), (2) community action research, (3) community participatory action research (BRYDON-MILLER, 1997), (4) community-based participatory action research (COLLINS et al., 2018; LEPORE; HALL; TANDON, 2021) and more, the purpose of all of which is change. Listening to voices and co-production of knowledge to engage in change are crucial components of the different types of participatory action research. The success of participatory action research depends on learning by doing, including mentoring

A basic action research is principally researcher-led, as a result of which, it is hierarchical: specifically, top-down. Community action research is also researcher-led and topdown. An example of a basic action research is an investigation that a teacher, as an objective observer, conducts in the classroom with a view to understand classroom-related problems and to change the situation for the better. An example of a community action research is one in which a lead investigator is an external expert who identifies community problems top-down for the purpose of the amelioration of community life. Participatory action research is reliant on dialogue in which the main researcher in engaged in horizontal communication with participants on the direction of the action research. In a basic action research, the investigator is the only active participant in the research. However, in a participatory action research, all participants are 


\section{Revista Brasileira de Diálogo Ecumênico e Inter-religioso}

actively engaged in the research and generate knowledge, as all are co-producers of knowledge. In additional, all participants in a participatory action research are actively engaged in the process and implementation of the project. A community participatory action research is community led, as the direction of the research is bottom-up, in which the voices from below osmoses to the lead researcher. This paper employed the community participatory action research (PAR) variant of action research (FRANSMAN et al., 2021). See figure 3 below.

\section{FIGURE 3 - DIFFERENT TYPES OF ACTION RESEARCH}

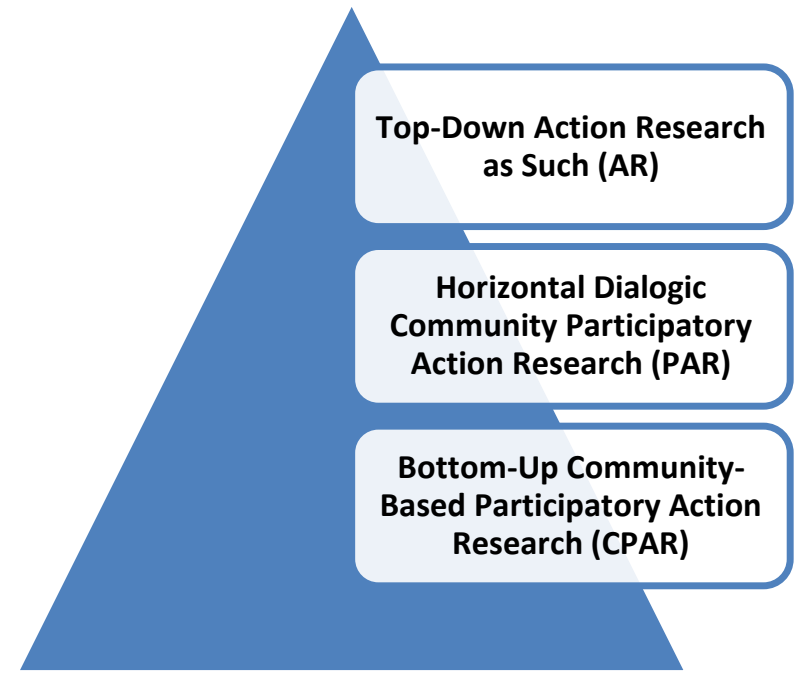

Source: The author.

\section{METHODOLOGY}

\subsection{Research design}

This research employed a qualitative case study research design in the form of a community participatory action research (CPAR). This interreligious and intercultural case study dealt with environmentalism both academically and practically. The research is community-based, as a religious leader initiated the call for an interreligious, intercultural educational and practical efforts to promote environmentalism. It is participatory, as the research assistant voiced the suggested and required inputs for the academic aspects, while the religious representatives provided inputs for the contents of the practical activities, including those surrounding the tree-planting event. It is a piece of research as the project required conceptualization, planning, literature review research, implementation of the project in the classroom and on the field, writing, and publication. See figure 4 below: 


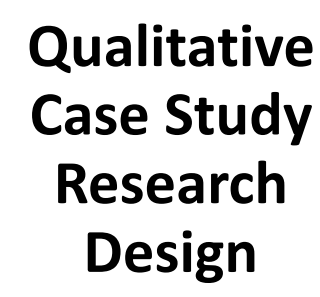

Dialogue with \& Involement of the Inter-Religious Community

and the Academic Community

Tree Planting

Inclusion in the Syllabus

Research

Source: The author.

\subsection{Reflexivity}

In the USA, the researcher has been involved in intercultural and interreligious engagement and collaboration since 2006 in youth peacebuilding as well as engaging in human rights, environmentalism, social justice, and peace efforts both on campus and in the community. Since 2016, he continued performing similar responsibilities in Thailand. In all these efforts, he ensures gender inclusion and balance at all levels of work. Hence, this participatory action research is a natural progression of his academic and social commitments.

\subsection{Sources of data}

In response to the first research question, the Bible provides inspiration and is the principal source of data that provides lessons on caring for water and life on Earth. In response to the second research question on the current environmental situation, sources include academic journals, news releases, and documents of non-governmental organizations. Sources from such groups as the World Council of Church provide reflections on care and service (WORLD COUNCIL OF CHURCH, 2021b) water (WORLD COUNCIL OF CHURCH, 2020), food (WORLD COUNCIL OF CHURCH, 2021c), care for creation and climate justice (WORLD COUNCIL OF CHURCH, 2021a), gender (WORLD COUNCIL OF CHURCH, 2021f), human dignity and rights (WORLD COUNCIL OF CHURCH, 2021d), justice and peace (WORLD COUNCIL OF CHURCH, 2021g) as well as interreligious and intercultural dialogue (WORLD COUNCIL OF CHURCH, 2021h, 2021e). In response to the third research question, the author is himself a research instrument who engaged in dialogue with both the academic community as well as the intercultural and interreligious community on the direction and implementation of the community participatory action research. 


\section{Revista Brasileira de Diálogo Ecumênico e Inter-religioso}

\subsection{Population and samples}

The population of this action research was dual: the academic community and the interreligious community. The samples from the academic community in northern Thailand included two instructors in an undergraduate general elective class, titled Truth and service. The samples from the interreligious community in northern Thailand included representatives of different faith traditions, namely: atheism, Baha'i, Buddhism, Christianity (Protestantism, Roman Catholicism, and Russian Orthodox Church), Hinduism, Islam, Judaism, Sikhism and traditional religions.

\subsection{Data collection method}

The research site of this case study involving an environmental participatory action research is at a university in northern Thailand. Data from the academic community are collected through a pre-test, a post-test, and a class critical reflection of the prior and new knowledge, skills, and attitudes of students on intercultural and intercultural advocacy and environmental care. Data about the wisdom from different faith traditions shall emerge from the interreligious community, which are collected by email communication as well as from the onsite sharing of religious representatives of different faiths who take part in the actual treeplanting program, including Atheism, Baha', Buddhism, Hinduism, Islam, Protestantism, Roman Catholicism, Russian Orthodox Church, Sikhism, and others.

\subsection{Data analysis method}

For analysis, this paper searched for key terms, coded them, organized the codes into themes, as well as developed a storyline for which a grounded theory emerges.

\subsection{Procedure and timeline}

This community participatory action research started in August 2021 in response to the call of the United Board for Christian Higher Education in Asia (UB) through the Institute for Advanced Study in Asian Cultures and Theologies (IASACT) of the Chinese University of Hong Kong (CUHK). Preparatory stage commenced thereafter with the guidance of mentors and guest speakers as well as from peers. Regular monthly research reports were presented, discussed, and critiqued online in lieu of in-site presentations in Hong Kong due to immobility across countries due to the pandemic. Planting ornamentals on campus grounds and potting of gift plants started in August 2021 and continues. Classroom sessions on environmental care takes place in early November 2021. The actual tree-planting activities take place in midNovember 2021, subject to change depending on the rise and fall of the spread of the COVID19 virus. Additional environmental projects could spill over to 2022, subject to community interest and the availability of excess funds. Overall, this community participatory action 
A participatory action research on the care for water and life on Earth research involves planning, implementation, evaluation, and feedback for sustainability. See figure 5 below:

FIGURE 5 - PROCEDURE OF THE COMMUNITY PARTICIPATORY ACTION RESEARCH
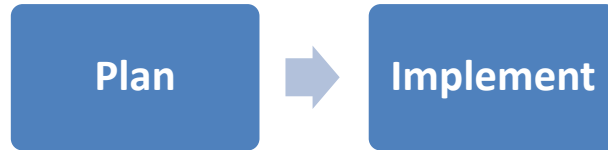

Evaluate

Feedback

Source: The author.

\subsection{Research ethics}

To protect personal identities and privacy with a view not to do any harm on research participants inadvertently, no names are cited in this report, for which reason consent was neither requested nor obtain from them.

\section{FINDINGS}

This section contained three subsections. The first one relates to some of the biblical lessons that discussed about caring for water and life and Earth. The second subsection deals with the contradictions between nature and society in the environmental situation obtaining today. The third subsection presents the findings of the specific participatory action research of this article.

\subsection{Lessons from the Bible about caring for water and life on Earth}

This section responded to the first research question: what are the lessons we can learn from the Bible about caring for water and life on Earth?

Biblical narratives are replete with stories about the relationship between nature on the one hand and human beings in society on the other hand (BIBLE, 2021). Water is vital to life itself, as the Earth on the one hand and the human body on the other hand are mostly composed of water.

The Pentateuch and the New Testament are replete with narrative of the relationship of human life with nature (BIBLE, 2021). In the Torah, we hear accounts of the creation of the world, in which water is an integral part of life on Earth. In the book of Genesis, when God created the world, water is so important to life on Earth that there are eleven references to water from verses 1 to 20 alone. Genesis 20-22 indicated that on the fifth day of creation, the waters brought forth life abundantly on Earth, which pleased God.

Genesis 7 discussed the story of Noah's time during which Noah's family found refuge in his ark which saved them from the flood waters but in which the sinners drowned. The ark provided a quarantine where Noah's family can escape from death due to drowning in the water. 


\section{Revista Brasileira de Diálogo Ecumênico e Inter-religioso}

Water was a vehicle on which Noah's ark navigated during the flood. Hence, water served dual function here.

In Exodus 15,22, Moses led the Israelites away from Egypt through the Red Sea on their way to the Desert of Shur. In Exodus 15,26, when the people became thirsty, God turned bitter water into sweet water for the Israelites to drink so that they may live. In Exodus 15,27, when the Israelites traveled further, they had access to twelve springs of water, beside which they camped.

In the New Testament, water continues to play an important role. Take for example the baptism of Jesus. In Mark 1,9, John baptized Jesus in the Jordan River. Baptism is a symbol of a new life or being born in the spirt of the Lord. In John 2,3, when Mary told Jesus that the wedding celebrants in Cana of Galilee ran out of wine, Jesus turned water into wine, which was his very first miracle. These are some water metaphors we read in the Bible, both in the Old Testament and in the New Testament, which reveal the importance of water in all aspects of human existence.

The Bible clearly establishes the linkage between water and trees. In Jeremiah 17:18, we read: "They will be like a tree planted by the water that sends out its roots by the stream. It does not fear when heat comes; its leaves are always green. It has no worries in a year of drought and never fails to bear fruit." In Psalm 1:3: 3, we read: "And he shall be like a tree planted by the rivers of water, that bringeth forth his fruit in his season; his leaf also shall not wither; and whatsoever he doeth shall prosper."

\subsection{The current water and environmental crisis}

This section responded to the second research question: what are the contradictions between nature and society with which humans are wrestling today?

Water is crucial for life. Even without going to school, everyone knows that without water, humans die. The current situation of the relationship between nature and society is a function of systemic environmental injustice. There is a water crisis in the world today, not only in poor countries, but also in affluent countries (KALLEN, 2015). Some of the major problems related to water today include: water scarcity, population growth, urbanization, drought, climate change, transboundary disputes, sanitation, disease, death, water pollution, and water disputes involving neighboring countries, fish versus farmers, power production versus domestic use, and power production versus endangered species (NEWTON, 2016).

The water crisis at times lead to wars (CHELLANEY, 2013). Rivers run dry, agricultural fields are parched, and drinking water is polluted and not potable (PEARCE, 2018). There is a water crisis in the Mediterranean (STEENHUIS; HOLST-WARHAFT; GRIECO, 2012), Yemen (Ward, 2015), India (RAY, 2011), South Asia (COLOPY, 2012), and in many other places. In the USA, for example, either there is a lack of water or the water supply in 
A participatory action research on the care for water and life on Earth many communities contain toxins and are not fit for human consumption (LASSITER; HOEY; CAMPBELL, 2020; MCGRAW, 2018).

The problem today also consists of privatizing water, which makes water a commodity for sale and profit and not treated as a basic necessity for life on Earth, including human life (BAKKER, 2010). Many companies are simply bottling municipal water after passing the water through reverse osmosis, charcoal filter, and ozone treatment but sold as magically superior water. Water is a public good and a human right. To sustain life on Earth and to have a good quality of life, we need clean air, and clean water. The World Council of Churches advocates for the preservation, accountable administration, and just sharing of water for all, on the basis that water is a public good for and a foundational right of all human beings (WORLD COUNCIL OF CHURCH, 2021).

\subsection{Community participatory action research}

This section responded to the third research question: what are specific courses of action to address the issue of water and life on Earth? Dialectically reflecting on the biblical teachings about water and life on Earth as well as on the environmental situation today, the researcher embarked on an environmental community participatory action research.

A religious leader from another faith first broached informally the idea of working together on an environmental project when the lead research was working in an Asia-wide international ecumenical organization. The suggestion to work together on environmentalism came up organically from friendly conversations. Then came the COVID-19 pandemic and the lead researcher's contract expired. When the main researcher started teaching at the university, this project matched the request of the faith representative. Hence, this research project was given a new breath of life. Thus was born the interreligious and intercultural tree-planting project.

Water is vital for the sustenance of life on Earth. Flora in general and trees in particular are some of the ways by which groundwater can be stored, used for irrigation and human consumption, for keeping the soil on the ground, as well as to avoid soil erosion and runoff from mountain or hill slopes (JONES, 2011). Thus, plants, including ornamentals and trees, among others, ensure the maintenance of the cycle of water that supports life on Earth. For this reason, this case study focuses on a planting project. See figure 6 below: 
Source: The author.

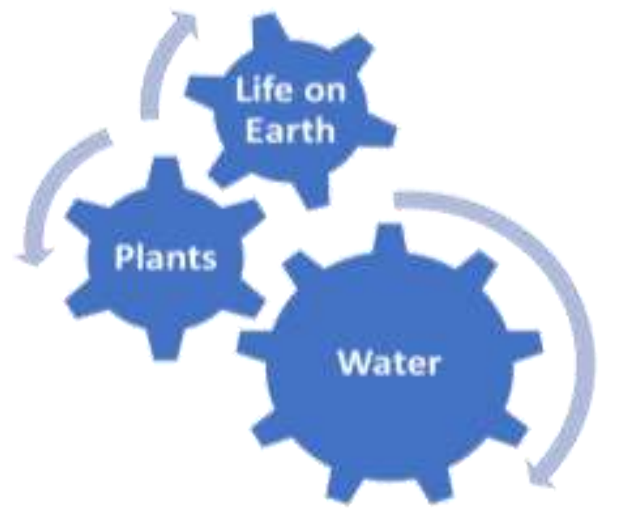

\subsection{Participation of two communities}

The participation in this environmental project involves two communities: the academic community and the interreligious community. For the academia, environmentalism is included as a new element of the curriculum. For the tree-planting activity, the interreligious community meets in person, while the students had options to watch the event on livestreaming or engage in intercultural or interreligious environmental project in their home cities or countries. See figure 7 below.

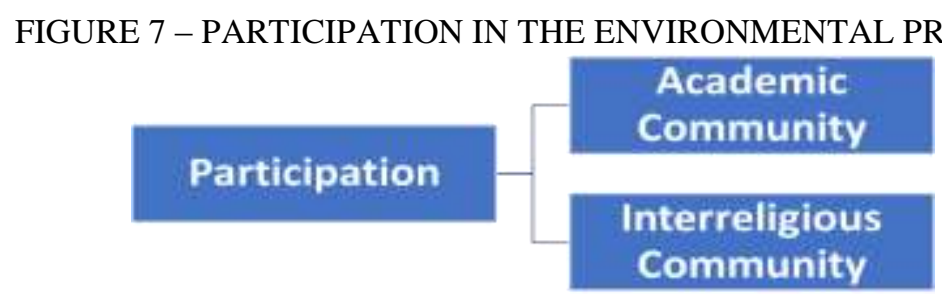

Source: The author.

This participatory action research involving the environment is inclusive, thereby involving people of (1) different cultures, including ethnicities and nationalities as well as (2) different religions, such as Atheism, Baha'i, Buddhism, Christianity (Protestantism, Roman Catholicism, and Russian Orthodox Church), Islam, Sikhism, and traditional religions. They come from different countries and continents as well as belong to different ethnicities within countries. See figure 8 below: 

RELIGION, AND THE ENVIRONMENT

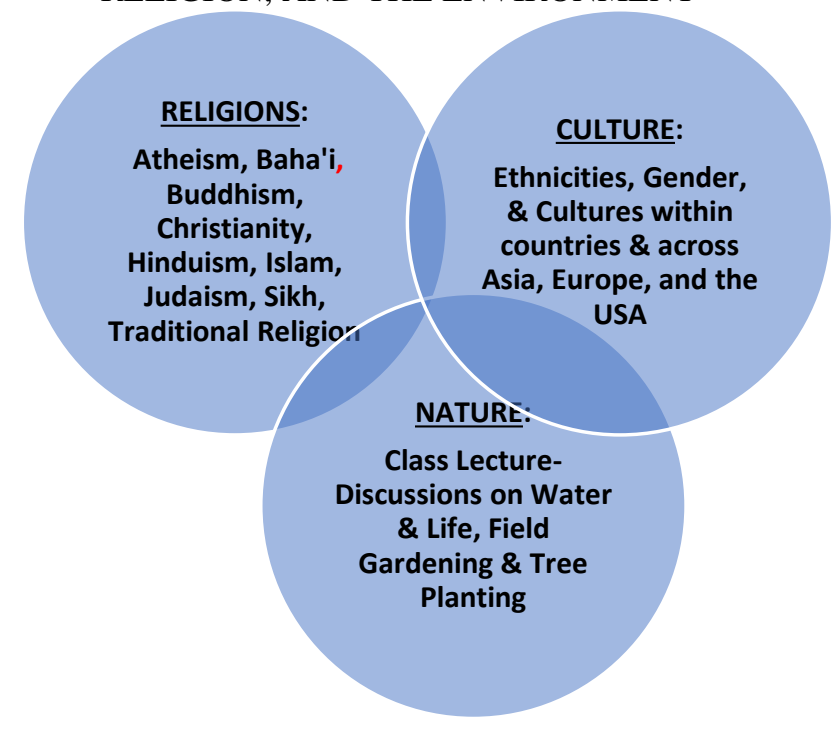

Source: The author.

\subsection{The pandemic changed everything}

By nature, action research is flexible and is like water that goes with the flow. Originally, this research not only aimed to be onsite but also multi-site, with tree planting taking place on campus on the one hand and in in the different locations of the places of worship of each religious representative on the other hand. Each student was supposed to be requested to engage in planting. However, due to the COVID-19 pandemic, it took a different turn. Health concerns included quarantine, lockdown, clustering, business closures, school closures, the use of face masks, hand sanitizers, and social distancing. First, classes at the university were only online in order to avoid the spread of the corona virus on campus. Second, the tree planting was to take place in only one site, gathering the interreligious fellowship as well as students, faculty, and staff.

\subsection{Social capital in intercultural and interreligious collaboration}

Clearly, organizing and gathering religious representatives of different faith traditions are difficult. However, the lead researcher has built social capital (ASQUITH, 2019; TZANAKIS, 2013) and social network with people of different cultures and faith representatives of different religions over the years in Thailand since 2016 up to this present writing. Hence, requesting them to take part in this tree planting was part of a natural progression of interreligious cooperation. For instance, from 2016 onwards (TY, 2018b), the principal researcher had been coordinating youth peacebuilding programs that included resource persons and participants who were Baha'i, Buddhists, Christians, Hindus, Muslims, and people of other faiths. 


\section{Revista Brasileira de Diálogo Ecumênico e Inter-religioso}

In 2017, the researcher brought Asia-wide participants to visit a Buddhist temple, a Hindu mandir, a Roman Catholic retreat house, a Sikh gurdwara, as well as invited two Muslim professors and one Roman Catholic priest, the purpose of which was to learn about the faith and social action of people of different faiths (CHRISTIAN CONFERENCE OF ASIA, 2017). During his human rights fact-finding mission to West Papua in December 2017 (TY, 2017), he planted an indigenous tree on the grounds of women's organization as part of nurturing our common concern for the plight of humanity regardless of sex, culture, ethnicity or color.

In 2018, the researcher coordinated an international consultation which planned an Asia-wide pilgrimage of justice for the year 2019, during which an interreligious fellowship to open the event (TY, 2018a). On March 4, 2019, the interreligious fellowship took place during which female and male leaders of the Baha'i, Buddhist, Hindu, Islamic, Protestant, Roman Catholic faiths led prayers for peace (CHRISTIAN CONFERENCE OF ASIA, 2019a). In November 2019, he coordinated the ninth Global Energy Parliament with the theme of Living in harmony with nature that had participants who were Baha'i, Buddhist, Hindu, and Protestant (CHRISTIAN CONFERENCE OF ASIA, 2019b). When the researcher personally went to the synagogue in town, he received positive feedback from the rabbi to join interreligious events related to peace. Unfortunately, upon consultation with the rabbi in Bangkok, the local rabbi backed out of any participation following the hierarchical decision. Despite continuing email communications with the synagogue, the rabbi never joined any interreligious gatherings. However, some Jewish friends are invited to attend events and are given the opportunity to speak about issues such as peace and environmentalism viewed from the Torah.

After developing social capital through networking with representatives of the different faith groups from 2016, the researcher and other religious representatives are often invited to important holidays of the different religions. These events included anniversaries and holy days. For example, one of the Hindu temples in town organized a public interreligious prayer in a well-known part of the city for the benefit of the mental health and physical health of the local people. The Hindu temple also organized its religious celebration with representatives of people from different faiths in attendance. The Baha'i community celebrated the two hundredth anniversary of its founder. The Sikh leader organized regular food pantry and food distribution to the local residents, all of whom have lost their jobs during the pandemic. The lead researcher of this article mobilized his local Thai friends who assisted in preparing, cooking, and packing over 250 food packs each time a food distribution is organized. The researcher also visited different temples occasionally and have informal conversations with monks on different matters. The priest or representative of the Russian Orthodox Church is also enjoined to take part in interreligious activities heretofore. Hence, there is a loose and informal but tightly knit interreligious community locally in town with ongoing amical and trusting relationships. See figure 9 below.

Caminhos de Diálogo, Curitiba, ano 9, n. 15, p. 156-176, jul./dez. 2021

168 ISSN 2595-8208 
A participatory action research on the care for water and life on Earth

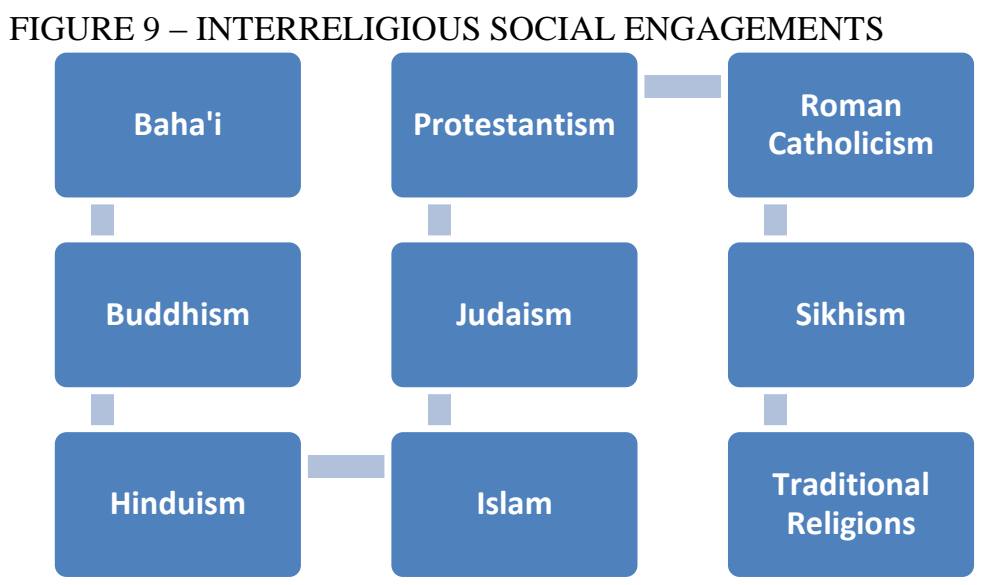

Source : Ty

\subsection{Environmental actions}

Tree planting and environmental concerns are not a new endeavor of the main researcher. In 2016, joining an environmental project of the Thai youth, he planted a lemon tree and a banana tree. In July 2016, after giving a presentation on the crisis of climate change (TY, 2020) to the joint Protestant and Roman Catholic Asian Movement for Christian Unity (AMCU), along with other participants, he planted a teak tree on the grounds of a university. In November-December 2016, he coordinated the Asian Christian Life-Giving Agriculture Forum (ACLGAF) in Thailand, after which organized a homestay for international participants in a Karen village outside of Chiang Mai, Thailand to learn about the indigenous lifestyle and sustainable agricultural system as well as engage in tilling the land to collect rain water which served as reservoir for irrigation as well as for raising fish and poultry (ASIAN CHRISTIAN LIFE-GIVING AGRICULTURE FORUM, 2016).

In November 2019, the researcher coordinated an international Eco-School for Water, Food and Climate Justice in Thailand. He facilitated some sessions and coordinated field visits related to the environment. He also assisted in the preparation of environmental action plans of voluntary community projects of each participant for implementation upon returning to their home communities in their own home countries.

\subsection{Preparation for the tree-planting activities}

In preparation of the actual tree planting event, the principal investigator purchases plants, organic compost, coconut coir, charcoal powder, soil, rice husk mulch, peat moss, vermicompost, garden tools, pots, seedling pellet blocks, vermiculite, perlite, pumice, magnesium sulfate, and other related planting materials. Then, two activities were put in place in a span of three months which involved planting. Plants were selected for the following reasons. The first activity involves planting in an unkempt university garden and the second activity involves potting gift plants for the participants. 


\subsubsection{Ornamental plants on campus for the Soul}

First, there is a patch of land which serves as a garden at the university. However, due to neglect over the years and decades, only rocks, stones, broken pots, shards, discarded cups, bowls, and plates, some garbage, single-use disposed plastics, and weeds are all that could be seen in the area. Hence, with the knowledge and permission of the department, the lead researcher removed as much as possible all the waste products but left the wild plants growing in the plot of land where the environmental project takes place. The principal investigator purchased ornamental plants, organic soil, animal manure, rice husks, and mulching materials and planted different flora after work in the evenings and on Saturdays and Sundays all by himself. These ornamentals, which were all sourced in Thailand, included, among others, amaryllis, arundina, Asian lilies, bird of paradise, caladium, cattleya, clay lotus bulbs, climbing rose plants, climbing rose seeds, crab's claw, dendrobium, gardenia, lantana, lavender, magnolia, night jasmine, peony seeds, purple heart, snake plant, vanda, verbena seeds, wandering Jew, and many others.

\subsubsection{Gift plants}

Second, gift plants were planted one by one in individual pots over several weeks, which included putting a soil filter at the bottom of each pot, after which organic soil is mixed with vermicompost, used coffee grounds, and other potting materials to help retain moisture as well as improve drainage to ensure healthy plant growth. Gift plants were chosen on the basis of their lifespan, ability to survive in the harshest conditions, and ease of propagation. The gift plants are green snake plants, green and yellow snake plants, and wandering Jews. This was a regular after-work hard labor for an urban man to do the planting himself and taking care of the plants every day over a period of three months alone in the evenings and during weekends. But this is in the service of the department in particular and the large academic community where it is situated.

However, after the university staffers pulled out the weeds from the plot of land as part of their work routine, the ornamental plants become very attractive by themselves. For this reason, many of the bright and colorful ornamental plants were pulled out of the soil and stolen one by one, not cuttings but whole plants, over several weeks after office hours and when no one is on campus during the weekends. The ongoing theft was reported to the building caretaker, security guard, the department chair, and the institute director.

\subsubsection{Fruit trees}

As for the intercultural and interreligious tree-planting event itself, some faculty members proposed at least two fruit bearing plants for the project. For this reason, a locally sourced cherry sapling and a walnut sapling were purchased ahead of time in preparing for the Caminhos de Diálogo, Curitiba, ano 9, n. 15, p. 156-176, jul./dez. 2021 170 ISSN 2595-8208 
A participatory action research on the care for water and life on Earth event to ensure that these plants are available prior to the occasion. The campus is lined with teak tree, which is hardwood that can be harvested as part of agroforestry. The ornamental plants bring joy to the human soul, while the fruit trees provide free food to those who will pick the fruits as they mature, which forms part of food security and food sovereignty. All flora maintain water from the rain and the soil and absorb carbon dioxide from the air to support life of Earth. See figure 10 below.

\section{FIGURE 10 - SELECTED PLANTS FOR THE ENVIRONMENTAL PROJECT}

\section{Selected Plants}

\section{Fruit Trees}

Food Security

\section{Ornamentals}

\section{Food for the Soul}

Source: The author.

\subsection{Tree-planting project}

There are several phases in the tree-planting project: the pre-event planning, gardening and tree planting per se, and the post-event evaluation.

\subsubsection{Pre-event actions}

For the tree-planting day itself, there are a series of activities, all of which are subject to change, depending on the increase or decrease in COVID-19 infections, which is like a pendulum-like swing in the city. A formal action plan proposal was prepared and submitted to the academic dean and vice president of the university, from whom approval was granted for the implementation of the project, on the proviso that there will not be more than fifty persons maximum in attendance. Due to the pandemic, the university officials prefer than students do their environmental projects at home. For those students who will not attend the tree-planting event in person, live-video-streaming, video recording, and photo documentation are available to them. Those who are in their homes in Thailand or in their home countries, due to pandemicrelated travel restrictions, will engage in intercultural or interreligious environmental projects.

With the approval on hand, a request was sent for university grounds workers to identify spots to dig holes for the two trees for the interreligious and intercultural planting ceremony as well as to borrow shovels for the occasion. Volunteers were recruited for video livestreaming, video documentation, photo documentation, and offering plant gifts to religious representatives. The already-purchased cherry sapling, walnut sapling, and gift plants are watered regularly. Food have already been ordered. In addition, supplementary food, drinks, soap, face masks, hand sanitizers, napkins, and other related items will be purchased on or right before the treeplanting day. Participation of religious leaders will be reconfirmed. Two additional day workers 


\section{Revista Brasileira de Diálogo Ecumênico e Inter-religioso}

were contracted to provide general assistance: from cleaning, prepping, setting up, photo and video shoots, collecting garbage, and washing dishes.

\subsection{Tree-planting activities}

On the day of the tree planting, the main event takes place at $2 \mathrm{pm}$. In the tradition of the popular education pedagogy of Freire, all participants engage in action and reflection during which discussions will be facilitated for community analysis (FREIRE, 2005). Activities include opening the event, explaining the origins and objectives of the event, reflections of each representative of different faith traditions in attendance from their scriptures, reflections of two students, offering plants to the religious representatives, simple meal together, informal fellowship, and evaluation. Some faith leaders and community members offered to bring some dishes to pass.

Originally, the event was open to the public. Due to COVID-19 restrictions, the university administration limits participation to a maximum of fifty persons only. Health and safety precautionary measures are put in place and shall be observed, including the use of face mask, hand sanitizer, soap and water, as well as social distancing.

Students who will not attend the event will watch the activities in live-video streaming. Home-based students in their countries conduct their own intercultural or interreligious environmental projects.

\subsection{Classroom teaching and student learning}

Students are evaluated as to the extent to which they learned from the classroom teaching on the relationship of culture, religion, environmentalism, and active citizenship as well as on the environmental action of tree-planting. The pretest and the posttest measure their old and new knowledge, skills, and attitudes or values. On November 4, 2021 the online pretest is administered to students in two undergraduate classes. On November 8, 2021, two classes jointly attend an online class session on interreligious engagements in Thailand over the years. On November 11, 2021, the two classes attend an online class session on culture, religion, environment, and active citizenship. On November 15, 2021, students either join the treeplanting event in person or by live-video-streaming or engage in their own environment project at home. On November 18, 2021, students engage in critical reflection on their participation in the tree-planting or environmental projects as well as fill out the online posttest. All these selfreflections by students provide both qualitative and quantitative measures of their learning outcomes in the online class critical reflection and in the pretest/posttest, respectively.

\subsection{Post-event sustainability plan}

Upon completion of the entire project, curricular materials shall be revisited with a view for the inclusion of environmental concerns in succeeding courses. The current revised Caminhos de Diálogo, Curitiba, ano 9, n. 15, p. 156-176, jul./dez. 2021 
A participatory action research on the care for water and life on Earth undergraduate course syllabus provides a sample of the concrete inclusion of environmental concerns in teaching and learning. The researcher shall include an environmental component in doctoral courses he teaches, such as human rights, research methodology, and the cultural dimensions of peacebuilding. Moreover, the researcher will follow up with religious representatives about our near future interreligious engagements, including environmental concerns.

Based on the findings of this paper, a grounded theory of this specific community participatory action research is developed, which summarizes the key elements of the project. See figure 11 below.

FIGURE 11 - GROUNDED THEORY OF COMMUNITY PARTICIPATORY ACTION RESEARCH

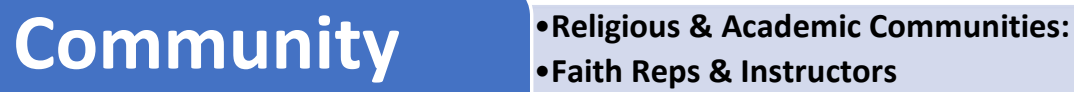 Participatory}

\section{Action}

-Environmental Advocacy: Changing the Curriculum \&

Teaching

-Environmental Care: Gardening, Gift Plants, \& Tree Planting

\section{Research}

Source: The author

\section{CONCLUSION}

In the findings section, this article responded to the first research question by reflecting upon the Old Testament and the New Testament, we learn that the Bible provide lessons about the importance of the care of water for life on Earth. This article replied to the second research, we observed the social realities in the world today, in which water crisis is a reality today due to several factors. However, the World Council of Churches reminds us that water must be treated as a public good and a human right, not as a commodity for sale and profit. This article answered the third research question by describing the community participatory action research involving the planting of ornaments and trees that involves the academic community and the interreligious community in northern Thailand, as trees are some of the means by which water is absorbed and maintained, which promotes life on Earth. Due to the COVID-19 pandemic health-related restrictions, this community participatory action research project took several twists and turns to go with the flow of the changing times. Its final outcome depends on the 
changing contours of the pandemic and the related openings or restrictions for people to gathering together in one place.

\section{REFERENCES}

ACTION RESEARCH CENTER (ARC). (2021). Mission and vision. Retrieved October 31, 2021, from https://cech.uc.edu/about/centers/arc.html

ASIAN CHRISTIAN LIFE-GIVING AGRICULTURE FORUM. (2016). Eco-Justice: Towards Sustainable Development and Food Security in Asia-4th (2016) Asian Christian Life-Giving Agriculture Forum. Seoul, South Korea: Asian Christian Life-Giving Agriculture Forum.

ASQUITH, L. (2019). Bourdieu and Social Capital. In L. Asquith (Ed.), Rebuilding Lives After Genocide: Migration, Adaptation and Acculturation (pp. 27-45). Cham: Springer International Publishing. https://doi.org/10.1007/978-3-030-14074-8_2

BAKKER, K. J. (2010). Privatizing water: Governance failure and the world's urban water crisis. Ithaca, N.Y: Cornell University Press.

BIBLE. (2021). King James Version. Retrieved from https://www.biblegateway.com/

BILORUSKY, J. A. (2021). Cases and Stories of Transformative Action Research: Five Decades of Collaborative Action and Learning (1st ed.). Abingdon, Oxon; New York, NY : Routledge, 2021.: Routledge. https://doi.org/10.4324/9781003156758

BRYDON-MILLER, M. (1997). Participatory action research. Journal of Social Issues, 53(4), 657-666.

CHRISTIAN CONFERENCE OF ASIA. (2017, May 29). Interfaith Training of Young Ambassadors of Peace in Asia (YAPA) begins. Retrieved October 31, 2021, from Christian Conference of Asia website: https://www.cca.org.hk/news-and-events/interfaith-training-ofyoung-ambassadors-of-peace-in-asia-yapa-begins/

CHRISTIAN CONFERENCE OF ASIA. (2019a, March 5). Christian Conference of Asia organised an Inter-Religious Fellowship and Dinner Reception in conjunction with the International Reference Group Meeting of the Pilgrimage of Justice and Peace of the World Council of Churches. Retrieved October 31, 2021, from https://www.facebook.com/ChristianConferenceofAsia/photos/pcb.2385214525036720/238521 2851703554/

CHRISTIAN CONFERENCE OF ASIA. (2019b, November 8). Global Energy Parliament focuses on the theme, 'Living in Harmony with Nature'-Christian Conference of Asia. Retrieved October 31, 2021, from https://www.cca.org.hk/news-and-events/global-energyparliament-focuses-on-the-theme-living-in-harmony-with-nature/

CHELLANEY, B. (2013). Water, peace, and war: Confronting the global water crisis. Lanham: Rowman \& Littlefield Publishers, Inc.

COLLINS, S. E., CLIFASEFI, S. L., STANTON, J., STRAITS, K. J., GIL-KASHIWABARA, E., RODRIGUEZ ESPINOSA, P., \& WALLERSTEIN, N. (2018). Community-based participatory research (CBPR): Towards equitable involvement of community in psychology research. American Psychologist, 73(7), 884.

COLOPY, C. (2012). Dirty, Sacred Rivers: Confronting South Asia's Water Crisis. Oxford; New York: Oxford University Press.

FRANSMAN, J., HALL, B., HAYMAN, R., NARAYANAN, P., NEWMAN, K., \& TANDON, R. (2021, January 21). Beyond partnerships: Embracing complexity to understand and improve research collaboration for global development. Retrieved October 31, 2021, from https://www.tandfonline.com/doi/full/10.1080/02255189.2021.1872507

FREIRE, P. (2005). Education for critical consciousness. London; New York: Continuum.

FREIRE, P. (2007). Pedagogy of the oppressed. New York: Continuum.

GULliON, J. S., \& TILTON, A. (2020). Researching with: A decolonizing approach to community-based action research. Leiden; Boston: Brill.

JONES, J. A. A. (Ed.). (2011). Sustaining Groundwater Resources: A Critical Element in the Global Water Crisis. Dordrecht: Springer Netherlands. https://doi.org/10.1007/978-90-4813426-7

KALLEN, S. A. (2015). Running dry: The global water crisis. Minneapolis: Twenty-First Century Books.

Caminhos de Diálogo, Curitiba, ano 9, n. 15, p. 156-176, jul./dez. 2021

174 ISSN 2595-8208 
A participatory action research on the care for water and life on Earth

KUMPERS, S., BRANDES, S., GEBHARDT, B., \& KUHNEMUND, C. (2021). [Roles and their dynamics in participatory research communities]. Bundesgesundheitsblatt, Gesundheitsforschung, Gesundheitsschutz, 64(2), 156-162. https://doi.org/10.1007/s00103-02003272-y

LASSITER, L. E., HOEY, B. A., \& CAMPBELL, E. (Eds.). (2020). I'm Afraid of That Water: A collaborative ethnography of a West Virginia water crisis. Morgantown: West Virginia University Press.

LEPORE, W., HALL, B. L., \& TANDON, R. (2021). The Knowledge for Change Consortium: A decolonising approach to international collaboration in capacity-building in community-based participatory research. Canadian Journal of Development Studies / Revue Canadienne d'études Du Développement, 42(3), 347-370. https://doi.org/10.1080/02255189.2020.1838887

MCGRAW, S. (2018). A Thirsty Land: The Making of an American Water Crisis. Austin: University of Texas Press. https://doi.org/10.7560/310311

NEWTON, D. E. (2016). The Global Water Crisis: A Reference Handbook. ABC-CLIO.

PEARCE, F. (2018). When the Rivers Run Dry: Water- the Defining Crisis of the Twenty-First Century. Boston: Beacon Press. Retrieved from http://library.lol/main/29358F7F99FFC0E244ACADF4A483415E

RAY, B. (2011). Climate change: IPCC, water crisis, and policy riddles with reference to India and her surroundings. Lanham, MD: Lexington Books.

STEENHUIS, T., HOLST-WARHAFT, G., \& GRIECO, M. (2012). Losing Paradise: The Water Crisis in the Mediterranean. Burlington, Vermont: Ashgate. Retrieved from https://ipfs.io/ipfs/bafykbzacebhyalh35vv2huwuqndhjqca2eq5qlhpgsjnqyj3murwtm6id366y?file name $=\% 28$ Voices $\% 20$ in $\% 20$ Development $\% 20$ Management $\% 29 \% 20$ Tammo $\% 20$ Steenhuis $\% 2$ C\%20Gail\%20Holst-Warhaft\%2C\%20Margaret\%20Grieco\%20-

\%20Losing\%20Paradise\%20_\%20The\%20Water\%20Crisis\%20in\%20the\%20MediterraneanAshgate $\% 20 \% 282012 \% 29 . p d f$

STRINGER, E. T., \& ARAGON, A. O. (2020). Action research. London: SAGE Publications. TY, R. (2017). Building Peace and Moving beyond Conflicts: Pastoral Solidarity Visit to West Papua. Chiang Mai, Thailand: Christian Conference of Asia.

TY, R. (2018a). Pilgrimage of Justice and Peace (PJP) Asia Focus 2019 Planning Meeting. In Christian Conference of Asia Programme Report 2018 (pp. 72-73). Chiang Mai, Thailand: Christian Conference of Asia.

TY, R. (Ed.). (2018b). Young Ambassadors of Peace in Asia (YAPA): Towards Peace with Justice and Human Security, Chiang Mai, Thailand, October 12-20, 2018. Christian Conference of Asia.

TY, R. (2020). The international political economy of nature and society: From climate emergency to climate justice in our common home. Caminhos de Diálogo, 7(11), 172.

TZANAKIS, M. (2013). Social capital in Bourdieu's, Coleman's and Putnam's theory: Empirical evidence and emergent measurement issues | Tzanakis | Educate . 13(2). Retrieved from http://www.educatejournal.org/index.php/educate/article/view/366

WALSH, M., GRANT, G., \& COLEMAN, Z. (2008). Action research-A necessary complement to traditional health science? Health Care Analysis: HCA: Journal of Health Philosophy and Policy, 16(2), 127-144. https://doi.org/10.1007/s10728-007-0064-6

WARD, C. J. (2015). The water crisis in Yemen: Managing extreme water scarcity in the Middle East (1. ed). London: Tauris.

WORLD COUNCIL OF CHURCH. (2020). Ecumenical Water Network | World Council of Churches. Retrieved November 1, 2021, from https://www.oikoumene.org/what-wedo/ecumenical-water-network

WORLD COUNCIL OF CHURCH. (2021a). Care for creation and climate justice | World Council of Churches. Retrieved November 1, 2021, from https://www.oikoumene.org/what-wedo/care-for-creation-and-climate-justice

WORLD COUNCIL OF CHURCH. (2021b). Diakonia and ecumenical solidarity | World Council of Churches. Retrieved November 1, 2021, from https://www.oikoumene.org/what-wedo/diakonia-and-ecumenical-solidarity

WORLD COUNCIL OF CHURCH. (2021). Ecumenical Water Network. Retrieved November 2, 2021, from https://www.oikoumene.org/what-we-do/ecumenical-water-network 
WORLD COUNCIL OF CHURCH. (2021c). Food for Life Campaign | World Council of Churches. Retrieved November 1, 2021, from https://www.oikoumene.org/programmeactivity/food-for-life

WORLD COUNCIL OF CHURCH. (2021d). Human Dignity and Rights | World Council of Churches. Retrieved November 1, 2021, from https://www.oikoumene.org/what-we-do/humandignity-and-rights

WORLD COUNCIL OF CHURCH. (2021e). Interreligious Dialogue and Cooperation | World Council of Churches. Retrieved November 1, 2021, from https://www.oikoumene.org/what-wedo/interreligious-dialogue-and-cooperation

WORLD COUNCIL OF CHURCH. (2021f). Just Community of Women and Men | World Council of Churches. Retrieved November 1, 2021, from https://www.oikoumene.org/what-wedo/just-community-of-women-and-men

WORLD COUNCIL OF CHURCH. (2021g). Pilgrimage of Justice and Peace | World Council of Churches. Retrieved November 1, 2021, from https://www.oikoumene.org/what-wedo/pilgrimage-justice-and-peace

WORLD COUNCIL OF CHURCH. (2021h). WCC and Center for Interreligious and Intercultural Dialogue commemorate 25 years of fruitful dialogue. Retrieved November 1, 2021, from World Council of Churches website: https://www.oikoumene.org/news/wcc-and-centerfor-interreligious-and-intercultural-dialogue-commemorate-25-years-of-fruitful-dialogue

ZYCH, M. M., BERTA, W. B., \& GAGLIARDI, A. R. (2020). Conceptualising the initiation of researcher and research user partnerships: A meta-narrative review. Health Research Policy and Systems, 18(1), 24. https://doi.org/10.1186/s12961-020-0536-9.

Recebido em: 20/10/2021. Aceito em: 26/11/2021. 